\title{
Urban ethnobotany: a case study in neighborhoods of different ages in Chapecó, Santa Catarina State
}

\author{
Aline Pradeiczuk', Mayra Teruya Eichemberg ${ }^{2}$ and Camila Kissmann ${ }^{3^{*}}$
}

Received: March 3, 2017

Accepted: April 3, 2017

\begin{abstract}
The study of urban home gardens is still a current gap in knowledge in Brazilian ethnobotany researches, especially in the south of Brazil. This study was carried out to survey the species composition of plants in urban residential home gardens of two neighborhoods in the municipality of Chapecó (state of Santa Catarina, southern Brazil): an older neighborhood created prior to the 1950s, and a younger neighborhood created in the decade 1970-1980. It was hypothesized that the home gardens in the older neighborhood would be larger and have greater species richness than those in the younger neighborhood. Data from 10 home gardens in each neighborhood were collected through semi-structured interviews. The plants cited by interviewees were classified as used for alimentary, medicinal and/ or ornamental purposes. A total of 372 plant species (256 in the older neighborhood and 248 in the younger one) were recorded. The two neighborhoods differed in the size of their home gardens, but had similar species richness. The high species richness of plants cultivated for alimentary, medicinal and ornamental purposes in both Chapecó neighborhoods indicates that these spaces are an important resource for food, subsistence and well-being.
\end{abstract}

Keywords: alimentary plants, ethnobotany, medicinal plants, ornamental plants, species composition, urban home gardens

\section{Introduction}

House-lot gardens refer to areas close to the houses intended for the production of agricultural and forestry species, which sometimes occur in association with the breeding of small domestic animals (Peyre et al. 2006). During colonial times, the use of house-lot gardens was linked to bodily functions such as food and rudimentary sanitary facilities (Silva 2004). In that time, the purpose of species cultivation was just to supply domestic food needs (Silva 2004) but over time, house-lot gardens have acquired other functions, becoming a common setting of human-environment interactions (Cook et al. 2012). As a component of urban agriculture, house-lot gardens have been recognized as spaces for agrodiversity and species conservation (WinklerPrins 2006).

The change in the use of house-lot gardens over time has followed socioeconomic changes resulting from the process of urbanization (Perna \& Lamano-Ferreira 2014). The unprecedented rural-urban migration that has occurred it the $21^{\text {st }}$ century has led to rapid urban growth (Stewart et al. 2013). Urban home gardens are a way of helping the transition from rural to urban living, being a link for the urban newcomers to their rural homes, as well as a way to sustain urban life (WinklerPrins 2006). Thus, currently, urban residential home gardens are areas intended for cultivation of medicinal plants as well as food species that supplement the diet of people, especially when these foods

\footnotetext{
${ }^{1}$ Curso de Ciências Biológicas, Universidade Comunitária da Região de Chapecó, Av. Atílio Fontana 591-E, Efapi, 89809-000, Chapecó, SC, Brazil ${ }^{2}$ Centro de Educação Superior do Oeste, Universidade do Estado de Santa Catarina, Rua Beloni Trombeta Zanin 680E, Santo Antônio, 89815-630, Chapecó, SC, Brazil

${ }^{3}$ Instituto de Biociências, Departamento de Botânica, Universidade Estadual Paulista Júlio de Mesquita Filho, Rua Professor Doutor Antonio Celso Wagner Zanin, s/nº 18618-689, Botucatu, São Paulo, Brazil

*Corresponding author: camilakissmann@ibb.unesp.br
} 
are sources of vitamins, minerals and fibers, such as fruits and vegetables (Amaral \& Guarim-Neto 2008; Siviero et al. 2011). In addition, the cultivation of species with ornamental purposes in urban residential home gardens is observed (Eichemberg et al. 2009; Vila-Ruiz et al. 2014), which contributes to conserving local biodiversity when native species are included (Smith et al. 2006).

Residential home gardens have always been a common feature in rural households. With the rural exodus, which was especially significant in the period 1960-1980 (Alves et al. 2011), most rural households moved to urban environments and began to reproduce their practices, habits, and knowledge in their urban residential home gardens, so that these places have become an element present in all households, regardless of social class or geographical location (Silva 2004). Ethnobotany is a multidisciplinary science that studies the direct interrelationships between people from different cultures and the plants in their environments (Albuquerque 2005) and, in the late 1990s, ethnobotanists realized that biocultural knowledge was not restricted to marginal communities but was also part of metropolitan areas, and they began to dedicate to urban ethnobotany studies (Pieroni \& Vandebroek 2007).

However, despite the importance of house-lot gardens for economic, medical or aesthetic purposes (Eichemberg et al. 2009; Siviero et al. 2011), home gardens studies have emerged recently among Brazilian ethnobotanical research (Ritter et al. 2015). Most of the ethnobotanical articles published in Brazil during 1988-2013 focused on medicinal purposes (59.8\%), whereas those that focused on general ethnobotany (studies addressing knowledge, use and management of plant resources in general) and specialized ethnobotany (studies addressing knowledge, use and management of plant resources for a particular purpose) represented $36.6 \%$ and those that focused on home gardens represented only $4.2 \%$ (Ritter et al. 2015). There are several reasons why studies about urban home gardens should be given more attention: first, due to their potential for biodiversity and germoplasm conservation (WinklerPrins 2006), especially when their species composition includes native species from local flora as well as rare species; second, because of the high number of exotic and potentially invasive plant species, whose control is of great economic and ecological importance (Manchester \& Bullock 2000); third, because urban home gardens can provide food in an environmentally sustainable way, preserving biodiversity and adding ecological and socioeconomic sustainability (Moura \& Andrade 2007); fourth, because urbanization is accelerating worldwide (UNDP et al. 2000) and it will certainly cause reduction in garden sizes and may potentially affect the species richness in such home gardens; and fifth, because of its contribution to the maintenance of social networks (Murrieta \& WinklerPrins 2006; WinklerPrins 2006).

In light of these concerns, there is the need for development of ethnobotanical studies to know the diversity of plants currently cultivated in urban home gardens and their traditional uses, as well as to better understand the house-lot gardens uses in the social context. Since the second half of the 1970s, the municipality of Chapecó, due to population growth and changes in the urban perimeter and subdivision, began to show social differentiation in the urban space with the highest income population being concentrated in the central area and the low-income population occupying peripheral areas (Reche 2008).

Urbanization has become a worldwide problem. In 2010 more than half of the world's population lives in urban areas (UN-Habitat 2010). At that time, approximately $85 \%$ of the Brazilian country's population was already concentrated in urban areas (IBGE 2010). A common problem for urban gardens is increased demographic pressure on available land. WinklerPrins \& Sousa (2005) have already highlighted that gardens in urban areas are shrinking and the space allocated to plants is decreasing because house-lots have become lots with more houses. According to these authors it denotes the need for studies to assess the implications of city growth in society and environment.

This study was carried out to survey the plant species composition in urban residential home gardens of two neighborhoods of different ages in the municipality of Chapecó (state of Santa Catarina, southern Brazil): an older neighborhood created prior to the 1950s, and a younger neighborhood created in the decade 1970-1980. It was hypothesized that the home gardens in the older neighborhood would be larger and have greater species richness, whereas the home gardens in the younger neighborhood would be smaller and have less species richness. Additionally, it was assessed if there is correlation between the house-lot gardens size and the number of species and categories of plant use.

\section{Materials and methods}

\section{Study area}

The municipality of Chapecó is located in the western

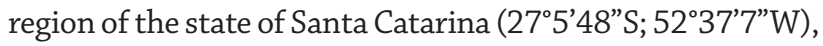
southern Brazil. According to IBGE (2010), the population of Chapecó in 2010 accounted for 198.188 inhabitants. In 2010, $93 \%$ of the population of Chapecó was residing in urban areas and only $7 \%$ in rural areas.

Chapecó, which was officially founded in 1946, is nowadays the largest and the main municipality in the western region of Santa Catarina (IBGE 2010). This municipality accounts for two of the largest industries of poultry and pork meat in the country - Brasil Foods (old Sadia) and Aurora - which makes the Santa Catarina the largest exporter of poultry meat in the world (Reche \& Sugai 2008). According to these authors, these companies were established in Chapeco in the late 1960s and early 1970s 
and have become the main drivers of rapid urbanization of the municipality, attracting migrants who left their countries in search of employment in the industry and better life conditions. In 2014, the Chapecó consisted of 31 neighborhoods (Favaretto \& Rammé 2015).

Two neighborhoods were assessed in this survey: 1 ) The Center neighborhood, created prior the 1950s; and 2) the Palmital neighborhood, created in the decade 19701980 (Fig. 1). The Center neighborhood had an estimated population of 13.060 inhabitants in 2010, being considered the $2^{\text {nd }}$ most populous neighborhood of the municipality of Chapecó, representing $7.77 \%$ of their population, distributed in an area of 273.1 hectares (ha) (Prefeitura Municipal de Chapecó 2010). In that same year, the Palmital neighborhood had a population of 4.311 inhabitants and was the $15^{\text {th }}$ most populous neighborhood in the municipality of Chapecó, representing 2.56\% of the population, distributed in an area of 194.4 ha (Prefeitura Municipal de Chapecó 2010).

\section{Method}

Data collection was conducted from October 2014 to February 2015. The participants of the survey were selected using the snowball sampling technique (Albuquerque \& Lucena 2004). The criteria for informant inclusion were: a) age of 18 or older; b) reside for at least 1 year in the neighborhood; c) be the garden manager or have knowledge about the plants that are cultivated in the house-lot gardens. They were assessed 10 urban house-lot gardens in Center and 10 in the Palmital neighborhood, with 15 women being interviewed (eight in the Center and seven in the Palmital neighborhood), four men (two in the Center and two in the Palmital neighborhood) and one couple (Palmital neighborhood). The survey was carried out with the person responsible for managing the home gardens. First of all, each person involved was asked to sign conditions for free and informed consent to authorize the collection, use and publication of data. The protocol for this research was approved by the Community University of Chapecó Region (UNOCHAPECÓ) Research Ethics Committee ( $\mathrm{n}^{\circ}$ 188/14). After they have been signed, the socioeconomic profile of participants was raised and a survey using a semistructured questionnaire in order to document the species, their common names and uses, was carried out. The total area $\left(\mathrm{m}^{2}\right)$ of the residential home gardens was recorded or measured when interviewees did not know to inform on this.

During each visit, vegetal specimen samples of all plants cultivated in the house-lot gardens were collected, with the exception of ornamental or rare species and those very common cultivated plant species which were identified in the field. Plants that could not be collected were recorded in photographs for further identification. In addition, scientific name, botanical family name, and growth forms were added for each plant. Species were grouped in botanical families according to the classification system of Angiosperm Phylogeny Group III (APG III 2009). The validity of the botanical names of species was verified in the database of the Missouri Botanical Garden (http://www. theplantlist.org/). The plant species were classified by the interviewees in one or more of the following categories of use: A - alimentary; $\mathrm{M}$ - medicinal; O - ornamental. The plants classified up to species level were classified in exotic, native to Brazil or native to Santa Catarina State, according to their origin based on the List of Species of the Brazilian Flora (http://www.floradobrasil.jbrj.gov.br) and on the database of the Missouri Botanical Garden (http://www. theplantlist.org/). We are aware that not all species that are native to Santa Catarina State are native to Chapecó region, due to a range of edaphoclimatic conditions along the state, but there was no data available about plants native to the western region of Santa Catarina state. In the state of Santa Catarina, which is located in the Atlantic Forest Biome, the forest vegetation are distributed in three phytoecological regions: the Ombrophylous Dense Forest, the Mixed Ombrophylous Forest and the Decidual Seasonal Forest (Klein 1978). In the western region of this state only the Mixed Ombrophylous Forest and the Decidual Seasonal Forest can be found (Vibrans et al. 2012). The climate type in the region of Chapecó, classified according to Köppen, is $\mathrm{Cfa}$ with rains regularly distributed throughout the year and severe frost (Köppen 1948). The maximum temperature of the region is around $40^{\circ} \mathrm{C}$ and the minimum temperature is below $0{ }^{\circ} \mathrm{C}$, with an average temperature around $17^{\circ} \mathrm{C}$ and $20^{\circ} \mathrm{C}$ (Pandolfo et al. 2002).

Only herbs, shrubs, trees and epiphytes species, native or exotic ones grown in the ground or in pots, were considered in this survey. Plants that provide soil-surface coverage such as grasses and weed species were not considered in the survey. The vegetal species samples were identified by comparison with basic reference and plant identification keys (Bärtels 2007; Souza \& Lorenzi 2012; Sobral et al. 2013), as well as by comparison with properly identified herbarium specimens available in the Herbarium of Universidade Comunitária da Região de Chapecó (UNO) and herbarium specimens from other national and international herbariums available online. The exsiccates were included in the UNO.

The richness of plant species was determined in each neighborhood considering the number of species inventoried in the survey. A Student $t$ test $(\mathrm{p}<0.05)$ was performed to check the richness of species between Center and Palmital neighborhoods. An analysis of variance (two-way Anova) $(p<0.05)$ was performed to compare the categories and neighborhoods. For this, categories were used as one of the factors (three levels - ornamental, alimentary and medicinal) and neighborhoods as the other factor (two levels). The Tukey's test was performed for post hoc comparisons of mean results at the $5 \%$ significance level. The floristic similarity among the two neighborhoods was evaluated 


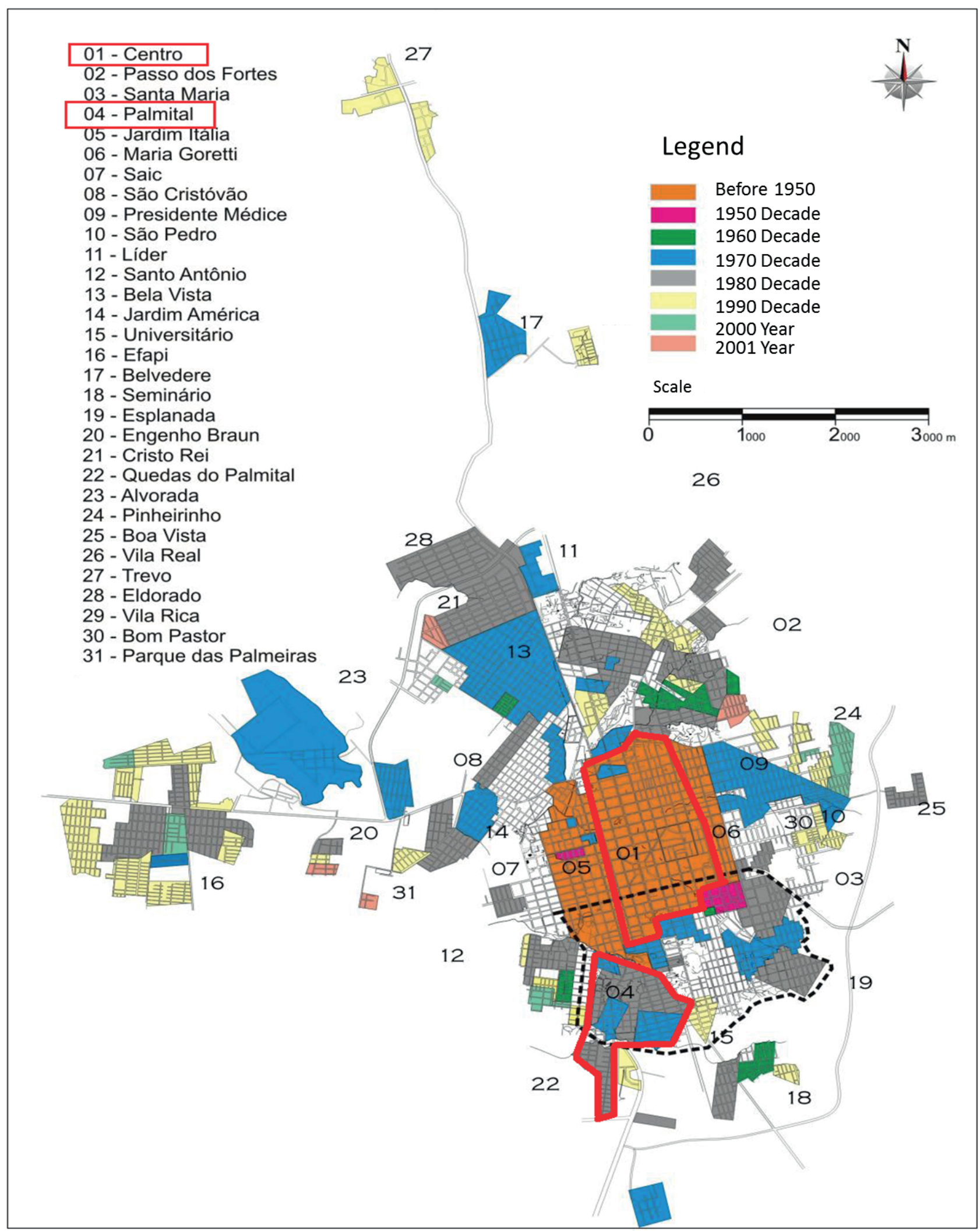

Figure 1. Chapecó neighborhoods classified according to their date of creation. The neighborhoods assessed in this study are highlighted with the red line. Adapted from Pawlak (2010). Please see the PDF version for color reference. 
using the Sørensen coefficient of similarity: $\mathrm{Ss}=(2 \mathrm{a}) /(2 \mathrm{a}+$ $b+c)$, where "a" corresponds to species present in the two neighborhoods, " $b$ " the number of species that occur only in neighborhood 1 , and " $c$ " the number of species that occur only in the neighborhood 2 (Pinto-Coelho 2000). The data of the areas of the urban-lot gardens of the two neighborhoods was transformed using the Box-Cox transformations (Box \& Cox 1964) and compared by Mann-Whitney test $(p<0.05)$. The correlation between the area of urban-lot gardens and the species richness (total of species) or categories, was performed using the Spearman correlation test $(p<0.05)$.

\section{Results}

The age of interviewees in both neighborhoods ranged from 31 years to over 60 years. Most interviewees were elderly (over 60 years), which accounted for $60 \%$ in the Center neighborhood and $40 \%$ in Palmital neighborhood. Low schooling among the interviewees of both neighborhoods was observed; $50 \%$ of interviewees from Center neighborhood and $70 \%$ from Palmital neighborhood had not finished basic education (between one and eight years of schooling). Regarding marital status, in the Palmital neighborhood almost all interviewees (90\%) were married, while in the Center neighborhood half of the interviewees were widow(er)is. In both neighborhoods, less than half of interviewees were born in the municipality of Chapecó ( $40 \%$ in Center and $30 \%$ in Palmital neighborhood). Most of them were born in the rural areas or in other cities in southern Brazil.

All interviewees of Palmital neighborhood came from the countryside, whereas in the Center neighborhood half the population $(50 \%)$ came from the countryside and half from the other urban areas. All the studied population possessed their own houses. Ninety per cent of interviewees from the Center neighborhood had lived for more than 20 years on their properties, whereas in the Palmital neighborhood, which was created later than the Center neighborhood, only $20 \%$ of respondents had lived on their properties for over 20 years.

A total of 372 plant specimens were recorded in the 20 urban house-lot gardens assessed in the two neighborhoods considered. Three hundred and twenty four of them were identified to species level (including 10 varieties), 15 to genus level, 13 only to botanical family level (Tab. S1 in supplementary material) and 20 individuals could not be identified. The species richness was similar in both neighborhoods ( $t=0.426 ; \mathrm{p}=0.675$ ), accounting for 256 species in Center neighborhood and 248 species in the Palmital neighborhood. There was no significant interaction between categories of use and neighborhoods $(\mathrm{F}=1.228$; 0.301). When the factors were analyzed separately we observed that both neighborhoods showed similar number of species cultivated in each category $(F=0.477 ; p=0.493)$ but there was differences between the categories of use $(\mathrm{F}=14.337 ; \mathrm{p}<0.001)$ in each neighborhood. In the Center neighborhood the number of ornamental species was higher than those observed for medicinal ones but it was similar to those of alimentary species, whereas in the Palmital neighborhood the number of ornamental species was higher than those observed for the other two categories (Fig. 2). The Sørensen similarity index also showed intermediate values indicating partial similarity regarding plant species composition between the two neighborhoods $(S s=0.60)$. The survey indicated high proportion (more than $75 \%$ ) of exotic species in all categories of use in both neighborhoods.

Nine of the 10 botanical families with the highest frequency of occurrence were common to both neighborhoods (Fig. 3). Lamiaceae was the most cited botanical family with 81 citations. This family was also the most representative regarding the number of species, being represented by 27 plant species (Fig. 4, Tab. S1 in supplementary material).

Among the most representative families in number of species, the interviewees from both Center and Palmital neighborhoods reported plants belonging to the three categories of use being from Lamiaceae, Asteraceae, Rutaceae, and Rosaceae families (Fig. 4). In both neighborhoods, Arecaceae, Araceae, and Cactaceae were represented only by ornamental and alimentary plant species whereas Orchidaceae and Asparagaceae were represented exclusively by ornamental species (Fig. 4).

In both neighborhoods, the most cited species used with ornamental purposes belonged to Orchidaceae family, whereas those used with medicinal purposes belonged to Lamiaceae family. Regarding the species used with alimentary purposes, the Lamiaceae and Rutaceae families came out among those with the highest numbers of species in Center whereas in the Palmital neighborhood a predominance of Rutaceae species was observed (Fig. 4).

The species more common in the house-lot gardens of the studied neighborhoods, taking both areas into consideration,

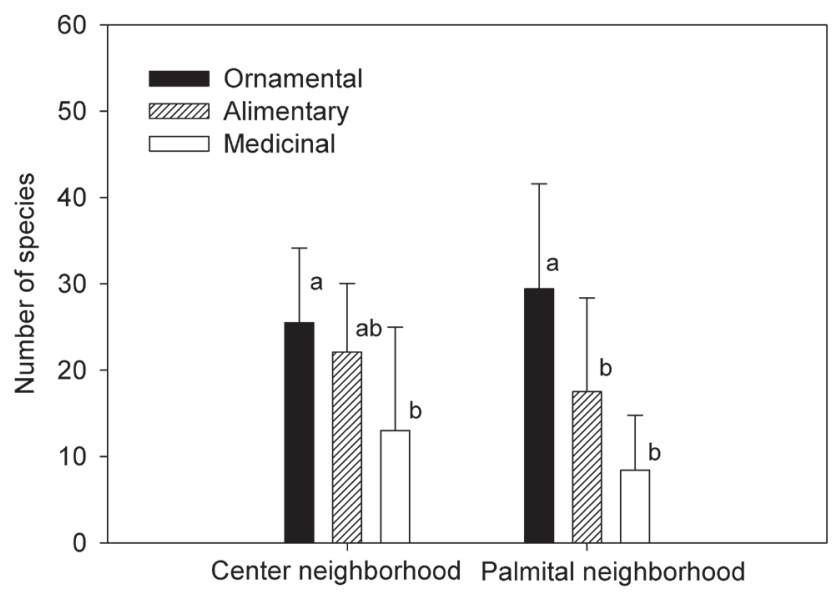

Figure 2. Number of species cultivated in the Center (A) and Palmital (B) neighborhoods in the municipality of Chapecó, state of Santa Catarina, Brazil classified in categories of use. The columns represent mean values and vertical bars $=S D$. Different letters indicate significant differences $(p<0.05)$ among categories of use. 


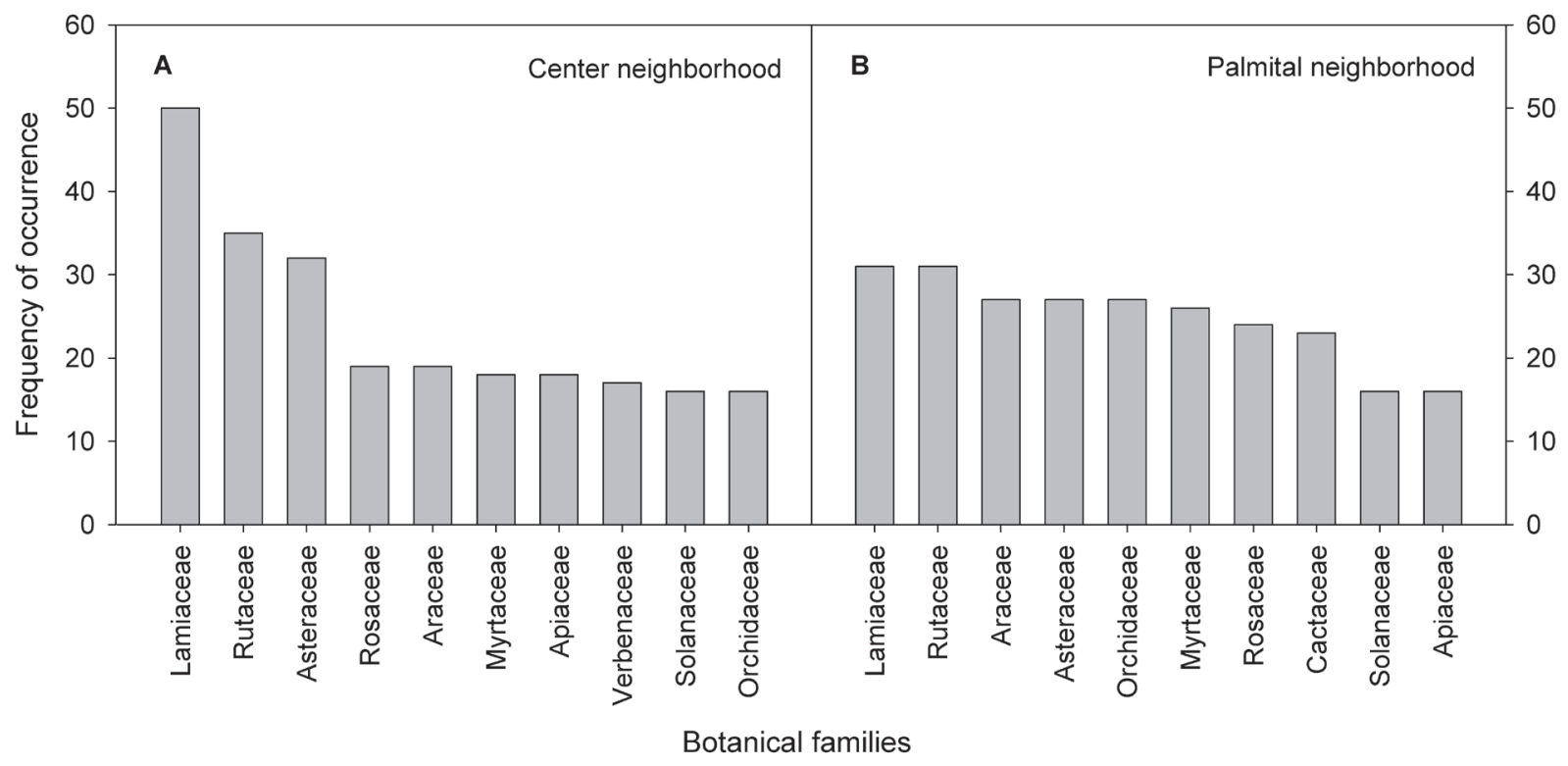

Figure 3. Botanical families with the highest frequency of occurrence reported by participants in the Center and Palmital neighborhoods in the municipality of Chapecó, state of Santa Catarina, Brazil.

were Kalanchoe blossfeldiana (17 records), Eugenia uniflora and Plinia cauliflora (15 records), and Dendrobium nobile, Petroselinum crispum and Catharanthus roseus with 14 records each. The vast majority of plant species surveyed were angiosperms, but in spite of this some gymnosperms species such as Araucaria angustifolia, Cycas revoluta and Chamaecyparis obtusa, ferns such as Adiantum raddianum, Dicksonia sellowiana, Equisetum giganteum, and species and varieties of Nephrolepis were also recorded (Tab. S1 in supplementary material).

A great variation among the size of house-lot gardens between Center and Palmital neighborhoods was observed $(\mathrm{U}=0.00 ; p<0.001)$. The median of the sizes of the urban landscapes in the Center neighborhood was $950 \mathrm{~m}^{2}$ and in the Palmital neighborhood the average size was $450 \mathrm{~m}^{2}$. Nevertheless, correlation analyses indicated no statistically significant associations between the size of house-lot gardens and the richness of species (total of species), ornamental, alimentary or medicinal species for both Center (ornamental: $\mathrm{r}=0.10, p=0.75$; alimentary: $\mathrm{r}=0.07, p=$ 0.83 ; medicinal: $\mathrm{r}=0.17, p=0.61$; total species: $\mathrm{r}=0.03, p$ $=0.92$ ) and Palmital neighborhoods (ornamental: $r=0.21$, $p=0.53$; alimentary: $\mathrm{r}=0.24, p=0.49$; medicinal: $\mathrm{r}=0.32$, $p=0.35$; total species: $r=0.36, p=0.29$ ).

\section{Discussion}

The two Chapecós neighborhoods with different ages assessed in this study differed regarding the size of the house-lot gardens but exhibited similar plant richness. The oldest neighborhood exhibited larger sizes of houselot gardens in comparison to the youngest neighborhood,

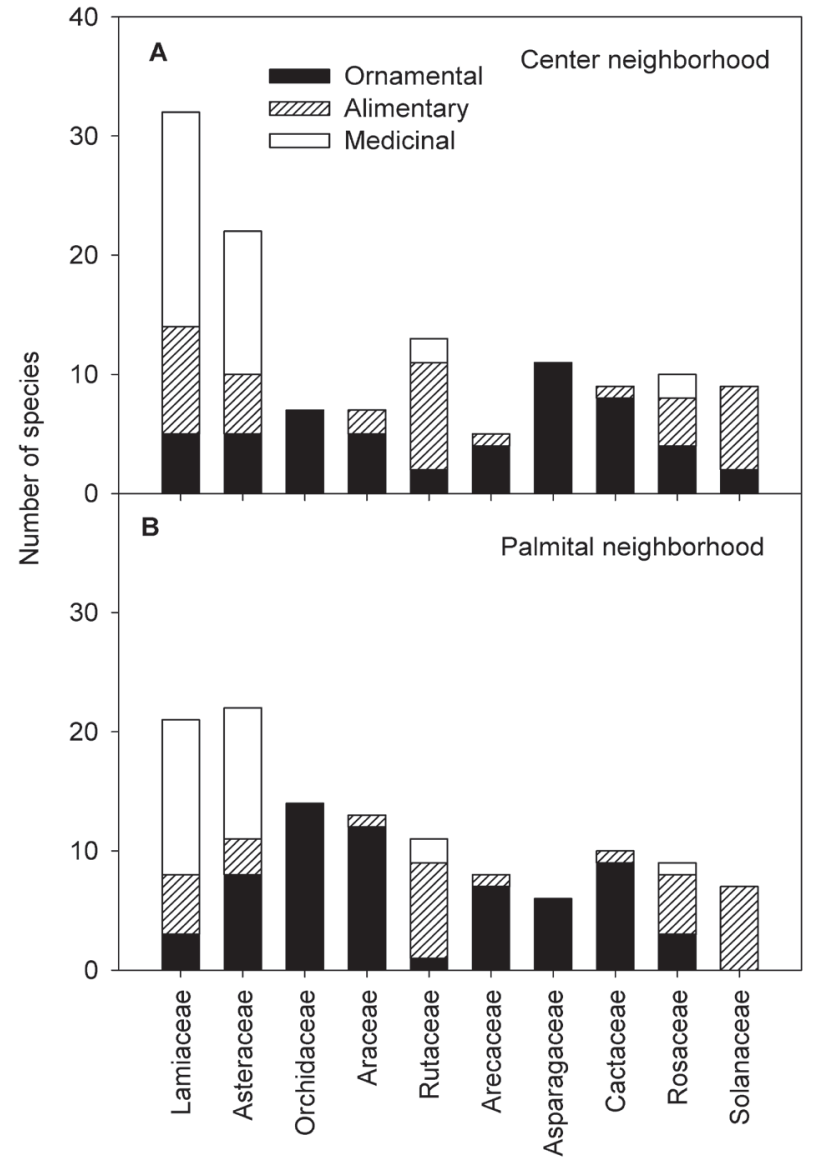

Figure 4. Most-represented botanical families in number of species per category of use in the Center (A) and Palmital (B) neighborhoods in the municipality of Chapecó, state of Santa Catarina, Brazil. 
confirming partially the hypotheses of this study once the house-lot gardens in the oldest neighborhood did not present higher species richness in comparison to the house-lot gardens in the youngest neighborhood. Such difference in the average size of home gardens between two neighborhoods probably is related to socioeconomic changes in their date of creation. Between the 1970s and 1980s, there was a considerable growth in the Chapecó City mainly due to due to consolidation of refrigerators companies in this city and the urban population during this period almost tripled, bringing considerable social and spatial consequences for the municipality, mainly due to the lack of city policies and action plans (Reche $\&$ Sugai 2008).

A positive correlation between species richness and age of the urban home gardens was found by Eichemberg et al. (2009) in the municipality of Rio Claro (São Paulo State), so that the older home gardens had the greater number of plant species. Similarly, in this study a greater richness of species in the oldest neighborhood compared with the youngest one was expected, as $90 \%$ of interviewees from the oldest neighborhood (Center) had lived for more than 20 years on their properties whereas in the youngest neighborhood (Palmital), only $20 \%$ of interviewees had lived on their properties for over 20 years. Nevertheless, this was not observed in this study.

In contrast to our prediction, no correlation was observed between house-lot gardens size and the number of species or the categories of plant use, indicating that people of both neighborhoods cultivate a diversity of plants with ornamental, alimentary or medicinal purposes, regardless of the size of the house-lot gardens. Such results suggest that, as observed by WinklerPrins (2006) in urban gardens in Santarém (Pará State, Brazil), the managers of house-lot gardens constructed such spaces to be utilitarian, productive and aesthetically pleasing to be in. Ávila et al. (2017) comparing the biodiversity of home gardens in quilombola communities with different degrees of urbanization also found that more urbanized communities have larger home gardens but not higher richness of plant species than the less urbanized communities, and they concluded that both communities are equally important for in situ conservation of native and introduced species.

The presence of an equivalent number of species in houselot gardens with different sizes indicates that people from the Palmital neighborhood, who have smaller house-lot gardens, found a way to optimize the space for plant cultivation. Indeed, considering that this peripheral neighborhood is mainly occupied by low-income population (Reche 2008), such high richness of species, especially those cultivated with food purposes, can significantly contribute to food security, as in much of Latin America where the food insecurity is a problem of access rooted in poverty (Rose 2008). Issues of food security have wide implications for people and their environments, especially in low and middle-income countries such as Brazil, considering that most of the population growth over the next few decades in such countries will be absorbed by cities, increasing the pressure on urban resources (Stewart et al. 2013). In this context, urban agriculture has been pointed out as a livelihood strategy that can improve food security of the urban poor with environmental benefits (Battersby \& Marshak 2013).

Similar to our results, no relationship between house-lot gardens size and species richness was found in the studies conducted in urban home gardens by Albuquerque et al. (2005) and Eichemberg et al. (2009), as well no relationship being found in those studies conducted in rural/semi-urban communities of Odeda (Nigeria) by Aworinde et al. (2013). Even so, Smith et al. (2006) noted that the size of urban gardens in Sheffield (UK) accounted for about a third of the variation in species richness. Notwithstanding, such authors emphasized that large increases in garden size resulted in only moderate changes in the species richness and they concluded that the behavior of garden managers (influenced by education, fashion, and advice) is likely to be a much stronger factor than garden size in determining species richness in gardens. In urban gardens in Santarém for example, the richness of species in urban house-lots is mainly related to the gift and barter exchange networks through which households have access to plants from different ecological niches (WinklerPrins 2006).

The age of people is a significant factor in popular knowledge about plants because older people usually have more accumulated experience and greater knowledge of the plant uses, especially regarding the medicinal ones (Eichemberg et al. 2009; Messias et al. 2015), as well as an increased concern about food safety so that they see the home gardens as an alternative source of nutrition (Eichemberg \& Amorozo 2013). In the present study, there was no difference between the neighborhoods regarding the number of species cultivated with alimentary and medicinal purposes although $60 \%$ of the interviewees in the Center neighborhood were over 60 years old whereas in the Palmital neighborhood only $40 \%$ of the interviewees were over 60 years old.

Studies about urban home gardens have confirmed their potential for biodiversity conservation (WinklerPrins 2006; Eichemberg et al. 2009). Eichemberg et al. (2009) recorded a great number of species cultivated with ornamental, alimentary or medicinal purposes in old urban home gardens in the municipality of Rio Claro (São Paulo state, Brazil). Another study carried out in the same municipality pointed out the important role that old urban home gardens play in supplying variation in the diet of habitants, allowing consumption of different types of products (Eichemberg \& Amorozo 2013). Urban gardens may have a great role in improving food security, especially in undeveloped regions (WinklerPrins 2006).

The high richness of species observed in the house-lot gardens of Chapecó reflects the strong relationship that these people maintain with nature. Urban home gardens with diverse plant species composition play an important role as 
habitats for biodiversity in urban systems, contributing to biodiversity conservation (Smith et al. 2006; WinklerPrins 2006). Old home gardens are especially important in saving rare species and/or species that were in the original area before the conversion of that area to extensive farming (Carniello et al. 2010).

Some hypotheses could be raised to explain such high richness of species found in this study, like the fact that all interviewees were migrants who came from the country or from other cities when they were still young and brought with them the germoplasm and knowledge about plant use acquired from their place of origin. Ladio \& Molares (2010) emphasized that throughout immigration, the cities are transformed into multiethnic spaces that share different traditions regarding the use of animals and plants brought by the migrants. Considering that Chapecó is the major and largest city in the west region of Santa Catarina state (IBGE 2010), which is composed of rural properties and small cities, probably the urban gardens represent a link between urban and rural settings so that products, germoplasm and household members move commonly between them, as was observed by WinklerPrins (2002) in Santarém (Pará State, Brazil). Another hypothesis is the high rate of change or donations of germoplasm among kin, neighbors, and communities, which is a common practice reported by several ethnobotany studies such as those of WinklerPrins (2006), Pasa et al. (2008), WinklerPrins \& Oliveira (2010), Milani et al. (2011), and Brito \& Senna-Valle (2011). Pasa et al. (2008) emphasized the importance of neighborly relations for the exchange of experiences and information. Another way of obtaining planting material is through purchase, which becomes more important as households obtain more cash income (WinklerPrins 2006). However, considering that the species richness was high and similar in both neighborhoods with social differentiation (Reche 2008), the last mentioned factor seems not be a significant source of obtaining germoplasm for gardens in the studied neighborhoods.

The high number of species cultivated with diverse purposes in both neighborhoods despite the low schooling of the interviewees, should also be noted. Indeed, knowledge about plant uses seems not be influenced by schooling of the interviewees, as related by Amaral \& Guarim-Neto (2008), Eichemberg et al. (2009) and Carniello et al. (2010). Knowledge, especially that related to the use of medicinal plants, seems to be predominantly developed through daily social contact among the kin and the community, which allows the transmission of information, beliefs and values (Ceolin et al. 2011).

A predominance of species of the Asteraceae and Lamiaceae families was observed, regardless of the neighborhood considered. Lamiaceae and Asteraceae, together with Solanaceae, were the families with the highest number of species in surveys in urban home gardens carried out by Eichemberg et al. (2009), Carniello et al. (2010),
Meyer et al. (2012) and Vásquez et al. (2014). This finding can be explained because of their cosmopolitan distribution and because such families include many species with bioactive compounds that are used with medicinal purposes (Di Stasi et al. 2002). In fact, $74 \%$ of the Lamiaceae species and $67 \%$ of Asteraceae species cited by interviewees in this study were cultivated (exclusively or not) with medicinal purpose.

In both neighborhoods assessed in this study, it was observed a great number of species cultivated with ornamental purpose. Women were reported as being mainly responsible for the maintenance of the urban-lot gardens in both neighborhoods and this finding can explain, at least partially, the high number of ornamental plants as women develop greater involvement in the cultivation of ornamental plants than do men (Eichemberg et al. 2009). According to Moreno-Black et al. (1996), the fact of women be mainly responsible for decisions concerning species, planting, care and use of the products in the home garden area is related to the home garden be a source of fresh plants and vegetables that are used for home consumption and women are who cook for the families. Notwithstanding, aside from the material benefits, home gardens are important to women because they are related to their domestic duties, labor patterns, productive decisions, aesthetic sensibilities and cultural roles (Howard 2006). Despite their knowledge regarding ornamental plants, in a general way women have extensive knowledge about medicinal plants because they are responsible for the preparation of medicines and for the health care of the family, while knowledge of men about medicinal plants is particularly restricted to species in the forest (Vásquez et al. 2014). Thus, house-lot gardens are a way for women to manifest specialized knowledge and skills without competing with men (Howard 2006). Besides choosing the species that will be planted and cared for in the urban-lot gardens, women often tolerate species that grow spontaneously in their gardens, especially if they are useful (Moreno-Black et al. 1996), which contributes to the high plant richness in these areas.

The predominance of ornamental species among plant uses was also reported in other studies in urban home gardens (Eichemberg et al. 2009; Batista \& Barbosa 2014), which may be a consequence of urbanization that makes people worry less about food and be more concerned with the aesthetic role of urban home gardens (Moura \& Andrade 2007). One major concern about ornamental plants is the high frequency of exotic species in this category. The ornamental horticulture industry is responsible for the introduction, propagation and transport of thousands of exotic plant species (Niemiera \& Holle 2009), some of which become invasive exotic species, representing a threat to native species, communities and ecosystems (Pimentel et al. 2001). The flora of urban domestic gardens probably forms the greatest source of potentially invasive exotic plants (Smith et al. 2006), so that such species should be cautiously managed to prevent escape, as they are considered the 
second biggest threat to the biodiversity of local fauna and flora, after habitat loss (Pimentel et al. 2001). Hovenia dulcis can be cited as an example of an invasive species recorded in this survey that represents a threat to Ombrophilous and Semi-Deciduous forests that occur in the western region of the Santa Catarina state (Zenni \& Ziller 2011).

Considering that house-lot gardens usually have a high number of varieties, they may be considered also as an important space for experimentation and domestication (Clement 2000). In northeastern Thailand, it was observed that a significant number of non-domesticated plants that were not tolerated when they appeared spontaneously had been actively transplanted and maintained in home gardens (Moreno-Black et al. 1996). It is concerning, especially considering the invasiveness of exotic plants.

The high richness of plants cultivated with alimentary, medicinal and ornamental purposes in urban-lot gardens in both Chapecó neighborhoods indicates the relevance of such spaces as a resource of food, subsistence, and wellbeing. Additionally, we observed high species richness regardless the size of the urban-lot gardens, which can contribute to food security in such peripheral urban areas. The high number of ornamental species cultivated in both neighborhoods suggests that the urban-lot gardens in Chapecó highlight the need to undertake actions aimed at increasing environmental public awareness regarding the threat of invasive exotic plants to biodiversity and the need for protection of native plants.

\section{References}

Albuquerque UP. 2005. Introdução à Etnobotânica. Rio de Janeiro, Editora Interciência.

Albuquerque UP, Andrade LHC, Caballero J. 2005. Structure and floristics of homegardens in Northeastern Brazil. Journal of Arid Environments 62: 491-506.

Albuquerque UP, Lucena RFP. 2004. Métodos e técnica para coleta de dados etnobotânicos. Recife, Livro Rápido/NUPPEA.

Alves E, Souza GS, Marra R. 2011. Êxodo e sua contribuição à urbanização de 1950 a 2010. Revista de Política Agrícola 20: 80-88.

Amaral CN, Guarim-Neto G. 2008. Os quintais como espaços de conservação e cultivo de alimentos: um estudo na cidade de Rosário Oeste (Mato Grosso, Brasil). Boletim do Museu Paraense Emílio Goeldi 3: 329-341.

APG III - Angiosperm Phylogeny Group. 2009. An update of the Angiosperm Phylogeny Group classification for the orders and families of flowering plants: APG III. Botanical Journal of the Linnean Society 161: 105-121.

Avila JVC, Mello AS, Beretta ME et al. 2017. Agrobiodiversity and in situ conservation in quilombola home gardens with different intensities of urbanization. Acta Botanica Brasilica 31: 1-10.

Aworinde DO, Erinoso SM, Ogundairo BO, Olanloye AO. 2013. Assessment of plants grown and maintained in home gardens in Odeda area Southwestern Nigeria. Journal of Horticulture and Forestry 5: 29-36.

Bärtels A. 2007. Guia de plantas tropicais. Rio de Janeiro, Lexikon.

Batista DL, Barbosa RI. 2014. Agrobiodiversidade urbana: composição florística, riqueza e diversidade de plantas nos quintais de Boa Vista, Roraima. Revista Brasileira de Agroecologia 9: 130-150.

Battersby J, Marshak M. 2013. Growing communities: integrating the social and economic benefits of urban agriculture in Cape Town. Urban Forum 24: 447-461.

Box GEP, Cox DR. 1964. An analysis of transformations. Journal of the Royal Statistical Society 26: 211-252.
Brito MR, Senna-Valle L. 2011. Plantas medicinais utilizadas na comunidade caiçara da Praia do Sono, Paraty, Rio de Janeiro, Brasil. Acta Botanica Brasilica 25: 363-372.

Carniello MA, Silva RS, Cruz MAB, Guarim Neto G. 2010. Quintais urbanos de Mirassol D'Oeste-MT, Brasil: uma abordagem etnobotânica. Acta Amazônica 40: 451-470.

Ceolin T, Heck RM, Barbieri RL, Schwartz E, Muniz RM, Pillon CN. 2011. Medicinal plants: knowledge transmission in families of ecological farmers in souther Rio Grande do Sul. Revista da Escola de Enfermagem da USP 45: 47-54.

Clement CR. 2000. Domestication of Amazonian fruit-crop: past, present and future. In: Vieira ICC, Silva JMC, Oren DC, et al. (eds.) Diversidade biológica e cultural da Amazônia. Belém, Museu Paraense Emílio Goeldi. p. 347-367.

Cook EM, Hall SJ, Larson KL. 2012. Residential landscapes as socialecological systems: a synthesis of multi-scalar interactions between people and their home environment. Urban Ecosystems 15: 19-52.

Di Stasi LC, Oliveira GP, Carvalhaes MA, et al. 2002. Medicinal plants popularly used in the Brazilian Tropical Atlantic forest. Fitoterapia 73: 69-91.

Eichemberg MT, Amorozo MCM. 2013. Contributions of the old urban homegardens for food production and consumption in Rio Claro, Southeastern Brazil. Boletim do Museu Paraense Emílio Goeldi 8: 745-755.

Eichemberg MT, Amorozo MCM, Moura LC. 2009. Species composition and plant use in old urban homegardens in Rio Claro, Southeast of Brazil. Acta Botanica Brasilica 23: 1057-1075.

Favaretto A, Rammé J, Afonso S. 2015. Parques urbanos: fragilidade na aplicação de legislação específica no município de Chapecó (SC). Paisagem e Ambiente: Ensaios 36: 177-208.

Howard PL. 2006. Gender and social dynamics in swidden and homegardens in Latin America. In: Kumar BM, Nair PKR. (eds.) Tropical homegardens: A time-tested example of sustainable agroforestry. Dordrecht, Springer Verlag. p. 159-182.

IBGE - Instituto Brasileiro de Geografia e Estatística. 2010. Santa Catarina: Chapecó. Brasília, IBGE. http://cidades.ibge.gov.br/xtras/perfil. php?codmun=420420. 20 out. 2015.

Klein RM. 1978. Mapa fitogeográfico do estado de Santa Catarina. In: Reitz R. (ed.) Flora ilustrada catarinense. Itajaí, Herbário Barbosa Rodrigues. 24 p.

Köppen W. 1948. Climatología con un estudio de los climas de la Tierra. Pánuco, Editora Fondo de Cultura Económica.

Ladio A, Molares S. 2010. Aspectos do estudo da dinâmica do uso de produtos etnobiológicos não tradicionais. In: Albuquerque UP, Lucena RFP, Cunha LVFC. (eds.) Métodos e técnicas na pesquisa etnobiológica e etnoecológica. Recife, Nupeea. p. 365-378.

Manchester SJ, Bullock JM. 2000. The impacts of non-native species on UK biodiversity and the effectiveness of control. Journal of Applied Ecology 37: 845-864.

Messias MCTB, Menegatto MF, Prado ACC, Santos BR, Guimarães MFM. 2015. Uso popular de plantas medicinais e perfil socioeconômico dos usuários: um estudo em área urbana em Ouro Preto, MG, Brasil. Revista Brasileira de Plantas Medicinais 17: 76-104.

Meyer L, Quadros KE, Zeni ALB. 2012. Etnobotânica na comunidade de Santa Bárbara, Ascurra, Santa Catarina, Brasil. Revista Brasileira de Biociências 10: 258-266.

Milani JF, Guido LFE, Barbosa AAA. 2011. Educação Ambiental a partir do resgate dos quintais e seu valor etnobotânico no distrito Cruzeiro dos Peixotos, Uberlândia, MG. Horizonte Científico 5: 1-32.

Moreno-Black G, Somnasang P, Thamathawan S. 1996. Cultivating continuity and creating change: Women's home garden practices in Northeastern Thailand. Agriculture and Human Values 13: 3-11.

Moura CL, Andrade LHC. 2007. Etnobotânica em quintais urbanos nordestinos: um estudo no bairro da Muribeca, Jaboatão dos Guararapes-PE. Revista Brasileira de Biociências 5: 219-221.

Murrieta RSS, WinklerPrins AMGA. 2006. 'Eu adoro flores!' Gênero, estética e experimentação agrícola em jardins e quintais de mulheres caboclas, baixo Amazonas, Brasil. In: Adams S, Murrieta RSS, Neves WA. (eds.) Sociedades caboclas amazônicas: modernidade e invisibilidade. São Paulo, Annablume. p. 277 - 294. 
Niemiera AX, Holle B. 2009. Invasive plant species and the ornamental horticulture industry. In: Interjit RL. (ed.) Management of invasive weeds. New York, Springer. p. 167-187.

Pandolfo C, Braga HJ, Silva Júnior VP, et al. 2002. Atlas climatológico do Estado de Santa Catarina. Florianópolis, Epagri.

Pasa MC, Neves WMS, Alcântara KC. 2008. Enfoque etnobotânico das categorias de uso das plantas na unidade de paisagem quintal, comunidade fazenda verde em Rondonópolis, MT. Biodiversidade 7: 3-13.

Pawlak SA. 2010. Pesquisa para desenho urbano de um complexo administrativo no setor centro sul da Avenida Getúlio Vargas na cidade de Chapecó-SC. Monograph, Universidade Comunitária da Região de Chapecó, Chapecó.

Perna TA, Lamano-Ferreira APN. 2014. Revisão bibliométrica sobre o cultivo de plantas medicinais em quintais urbanos em diferentes regiões do Brasil (2009-2012). UNOPAR Científica Ciências Biológicas e da Saúde 16: 61-7.

Peyre A, Guidal A, Wiersum KF, Bongers F. 2006. Dynamics of home garden structure and function in Kerala, India. Agroforestry Systems 66: 101-115.

Pielou EC. 1975. Ecological diversity. New York, Wiley-Interscience.

Pieroni A, Vandebroek I. 2007. Travelling cultures and plants: The ethnobiology and ethnopharmacy of migrations. New York, Berghahn Books.

Pimentel D, Mcnair S, Janecka J, et al. 2001. Economic and environmental threats of alien plant, animal, and microbe invasions. Agriculture, Ecosystems \& Environment 84: 1-20.

Pinto-Coelho RM. 2000. Fundamentos em ecologia. Porto Alegre, Artmed Editora.

Prefeitura Municipal de Chapecó. 2010. Plano de saneamento para os setores de abastecimento de água esgotamento sanitário do município de Chapecó/SC. Contrato 256/2010. Chapecó, Prefeitura Municipal de Chapecó.

Reche D. 2008. Leis e planos urbanos na produção da cidade: o caso de Chapecó, SC. MsC Thesis, Universidade Federal de Santa Catarina, Florianópolis.

Reche D, Sugai MI. 2008. A influência do capital agroindustrial na distribuição sócio-espacial urbana do município de Chapecó no sul do Brasil. In: Actas del X Coloquio Internacional de Geocrítica - Diez años de cambios en el Mundo, en la Geografía y en las Ciencias Sociales, 1999-2008. Barcelona, Universidad de Barcelona. <http://www.ub.es/ geocrit/-xcol/257.htm>. 13 Apr. 2015.

Ritter MR, Silva TC, Araújo EL, Albuquerque UP. 2015. Bibliometric analysis of ethnobotanical research in Brazil (1988-2013). Acta Botanica Brasilica 29: 113-119.

Rose DD. 2008. Interventions to reduce household food insecurity: a synthesis of current concepts and approaches for Latin America. Revista de Nutrição 21: 159-173.

Silva LO. 2004. Os quintais e a morada brasileira. Cadernos de arquitetura e urbanismo 11: 61-78.
Siviero A, Delunardo TA, Haverroth M, Oliveira LC, Mendonça MAS. 2011. Cultivo de espécies alimentares em quintais urbanos de Rio Branco, Acre, Brasil. Acta Botanica Brasilica 25: 546-553.

Smith RM, Thompson K, Hodgson JG, Warren PH, Gaston KJ. 2006. Urban domestic gardens (IX): Composition and richness of the vascular plant flora, and implications for native biodiversity. Biological Conservation 129: 312-322.

Sobral M, Jarenkow JA, Brack P, Irgang B, Larocca J, Rodrigues RS. 2013. Flora Arbórea e Arborescente do Rio Grande do Sul, Brasil. 2nd. edn. São Carlos, RiMA/Novo Ambiente.

Souza V, Lorenzi H. 2012. Botânica sistemática: guia ilustrado para identificação das famílias de fanerógamas nativas e exóticas no Brasil, baseado em APG III. 3rd. edn. Nova Odessa, Instituto Plantarum.

Stewart R, Korth M, Langer L, et al. 2013. What are the impacts of urban agriculture programs on food security in low and middle-income countries? Environmental Evidence 2. DOI: 10.1186/2047-2382-2-7.

UNDP - United Nations Development Programme, United Nations Environment Programme, World Bank \& World Resources Institute. 2000. World Resources 2000-2001: People and ecosystems-the fraying web of life. Amsterdam, Elsevier Science.

UN-Habitat 2010. State of the world's cities 2010/2011 - Cities for all: bridging the urban divide. http://www.unhabitat.org/content. asp?cid=8051\&catid=7\&typeid=46\&subMenuId=0.12 Feb. 2017.

Vásquez SPF, Mendonça MS, Noda SN. 2014. Etnobotânica de plantas medicinais em comunidades ribeirinhas do município de Manacapuru, Amazonas, Brasil. Acta Amazônica 44: 457-472.

Vibrans AC, Sevegnani L, Gasper AL, Lingner DV. 2012. Inventário florístico florestal de Santa Catarina. Vol. I. Diversidade e conservação dos remanescentes florestais. Blumenau, Edifurb.

Vila-Ruiz CP, Meléndez-Ackerman E, Santiago-Bartolomei R, et al. 2014. Plant species richness and abundance in residential homegardens across a tropical watershed: implications for urban sustainability. Ecology and Society 19: 22. http://dx.doi.org/10.5751/ES-06164190322

WinklerPrins AMGA. 2002. House-lot gardens in Santarém, Pará, Brazil: Linking rural with urban. Urban Ecosystems 6: 43-65.

WinklerPrins AMGA. 2006. Urban house-lot gardens and agrodiversity in Santarém, Pará, Brazil: Spaces of conservation that link urban with rural. In: Zimmerer KS. (ed.) Globalization and new geographies of conservation. Chicago, University of Chicago Press. p. 121-140.

WinklerPrins AMGA, Oliveira PSS. 2010. Urban agriculture in Santarém, Pará, Brazil: diversity and circulation of cultivated plants in urban homegardens. Boletim do Museu Paraense Emílio Goeldi 5: 571-585.

WinklerPrins AMGA, Souza PS. 2005. Surviving the City: Urban Homegardens and the Economy of Affection in the Brazilian Amazon. Journal of Latin American Geography 4: 107-126.

Zenni RD, Ziller SR. 2011. An overview of invasive plants in Brazil. Revista Brasileira de Botânica 34: 431-446. 